DOI: 10.34015/2523-4552.2019.1.13

УДК 343.8

Кузь I. I.,

аспірант кафедри кримінології та

кримінально-виконавчого права

Національної академії внутрішніх справ

e-mail: iryna.kuz1771@gmail.com

\title{
ПРАВОВЕ РЕГУЛЮВАННЯ ВЗАЄМОДІЇ ОРГАНІВ ТА УСТАНОВ ВИКОНАННЯ ПОКАРАНЬ 3 РЕЛІГІЙНИМИ ОРГАНІЗАЦІЯМИ
}

У статті розглянуто правові засади здійснення взаємодії органів та установ виконання покарань 3 релігійними організаціями 3 питань запобігання злочинності. Проаналізовано міжнародні нормативно-правові акти, вітчизняні закони та підзаконні нормативно-правові акти, які забезпечують право на свободу віросповідання в місцях позбавлення волі.

Ключові слова: права людини; свобода віросповідання; запобігання злочинам; капелан; релігійні організацї̈; установи виконання покарань.

В статье рассмотрены правовые основы осуществления взаимодействия органов и учреждений исполнения наказаний с религиозными организациями в вопросе предупреждения преступности. Проанализированы международные нормативно-правовые акты, отечественные законы и подзаконные нормативно-правовые акты, которые обеспечивают право на свободу вероисповедания в местах несвободы.

Ключевые слова: права человека; свобода вероисповедания; предотвращение преступлений; капеллан; религиозные организации; учреждения исполнения наказаний.

Постановка проблеми. Відповідно до частини 2 статті 50 Кримінального кодексу України покарання має на меті не тільки кару, а й виправлення засуджених, а також запобігання вчиненню нових злочинів як засудженими, так і іншими особами. Проте для ефективної організації виховного процесу та подальшої ресоціалізації, забезпечення правопорядку та запобігання повторному вчиненню кримінальних правопорушень недостатньо зусиль лише працівників пенітенціарних установ.
Концепцією реформування (розвитку) пенітенціарної системи України від 13.09.2017 № 654-р одним із основних завдань визначено підвищення ефективності протидії злочинності та забезпечення правопорядку в органах і установах ДКВС, а також максимальне залучення громадських організацій до роботи із засудженими [1].

Як свідчить практика, виконання цього завдання потребує консолідації зусиль пенітенціарних установ 3 тими інституціями громадянського 
суспільства, які готові співпрацювати і відповідно до закону можуть це здійснювати. Серед широкого кола організацій особливу роль відіграють релігійні. Крім того, загальновідомо, що релігія як форма духовної культури має великий позитивний вплив на морально-духовний розвиток людини і формування її правосвідомості та законослухняності. У зв'язку з цим виникає необхідність дослідження ряду питань, присвячених законодавчому забезпеченню взаємодії релігійних організацій 3 пенітенціарними установами.

Аналіз останніх досліджень і публікацій. Окремі аспекти взаємозв'язку релігійних організацій з пенітенціарними установами з питань ресоціалізації та виправлення засуджених, запобігання злочинам уже були предметом досліджень О. А. Дуки, М. І. Жолтані, О. Г. Колба, М. В. Палія, І. В. Пахомова, Г. Д. Радова, O. С. Стеблинської та ін. Роботи вказаних авторів мають суттєве наукове і практичне значення. Але праці більшості науковців не містять комплексного всеохопного наукового огляду питання нормативно-правового забезпечення взаємодії релігійних організацій $з$ установами виконання покарань.

Постановка завдання. Метою статті $\epsilon$ досягнення наукового результату у вигляді аналізу міжнародних та вітчизняних нормативноправових актів, які регламентують питання взаємодії релігійних організацій з органами та установами виконання покарань для запобігання злочинності як серед засуджених, так і осіб, які звільнились з пенітенціарних установ.

Виклад основного матеріалу. Свобода віросповідання закріплена в міжнародних та вітчизняних нормативно-правових документах. Зокрема, у статті 18 Загальної декларації прав людини йдеться про те, що: «Кожна людина має право на свободу думки, совісті і релігії; це право включає свободу змінювати свою релігію або переконання і свободу сповідувати свою релігію або переконання як одноособово, так і разом з іншими, прилюдним або приватним порядком в ученні, богослужінні і виконанні релігійних та ритуальних обрядів». Крім того, стаття 35 Конституції України встановила: «Кожен має право на свободу світогляду і віросповідання. Це право включає свободу сповідувати будь-яку релігію або не сповідувати ніякої, безперешкодно відправляти одноособово чи колективно релігійні культи і ритуальні обряди, вести релігійну діяльність».

Захист прав людини є однією 3 основ демократії, а захист прав засуджених осіб становить підгрунтя для здійснення демократичної карної політики - правильно зазначає O. С. Стеблинська [2, с. 50]. Однак на сучасному етапі демократизації українського суспільства надзвичайно гостро постає проблема забезпечення прав людини в місцях позбавлення волі. Водночас згідно зі статтею 4 Закону України «Про свободу совісті та релігійні організації» здійснення свободи сповідувати релігію або переконання підлягає лише тим обмеженням, які необхідні для охорони громадської безпеки та порядку, життя, здоров'я і моралі, а також прав і свобод інших громадян, встановлені законом і відповідають міжнародним зобов'язанням України.

Зазначені положення повністю відповідають закріпленим у частині другій статті 9 Конвенції про захист 
прав людини і основоположних свобод умовам, за наявності яких можливе обмеження прав і свобод людини, а саме: обмеження мають бути встановлені законом та вони є необхідними в демократичному суспільстві. До того ж, як неодноразово зазначалося в рішеннях Європейського суду з прав людини, у пункті 2 статті 11 і так само статті 9 Конвенції, втручання держави в реалізацію права на свободу віросповідання може бути виправданим, якщо воно «встановлено законом» та здійснено «згідно із законом», оскільки оскаржувані заходи повинні не тільки мати законодавче підгрунтя, а й передбачатися якісним законом, який має бути достатньо доступним, тобто бути сформульованим у спосіб, який дає змогу кожній особі - у разі потреби, за допомогою відповідної консультації регулювати свою поведінку (Рішення у справах «Larissis and Others v. Greece» від 24.02.1998 та «Metropolitan Church of Bessarabia and Others v. Moldova» від 13.12.2001) [3].

Варто погодитися з М. І. Жолтані, що релігійний вплив на засуджених вважався визначальним для організації всієї процедури виконання кримінального покарання та досягнення його мети ще з моменту започаткування досліджень проблематики цього покарання, адже мети покарання, що полягає в забезпеченні громадської безпеки і відновлення соціальної гармонії, порушеної злочином, можна досягти лише за умови відновлення гармонії в душі самого злочинця на основі принципів гуманізму та індивідуального підходу [4].

Нормативно-правова основа, яка регулює участь релігійних організацій у діяльності УВП, включає міжнародно-правові документи, закони
України та підзаконні нормативноправові акти.

Міжнародні нормативноправові документи, які регламентують душпастирську опіку засуджених та осіб, які тримаються під вартою, визначають їх невіддільне право на свободу віросповідання. До них належать:

- Загальна декларація прав людини (прийнята 10.12.1948);

- Конвенція про захист прав людини i основоположних свобод (прийнята 04.11.1950);

- Міжнародний Пакт про громадянські та політичні права (прийнятий 16.12.1966);

- Європейські пенітенціарні правила (прийняті 12.02.1987);

- Правила ООН, які стосуються захисту неповнолітніх, позбавлених волі (прийняті 14.12.1990);

- Основні принципи релігійної свободи і допомоги у в'язниці (прийняті 19.04.2010);

- Мінімальні стандартні правила поводження з ув'язненими (Правила Мандели, прийняті 1822.05.2015) [5, с. 47].

Визначальними міжнародними нормативно-правовими актами, які проголошують право на свободу релігії, є Загальна декларація прав людини, Конвенція про захист прав людини і основоположних свобод та Міжнародний Пакт про громадянські та політичні права.

Досить детально душпастирську опіку засуджених регламентують Мінімальні стандартні правила поводження з в'язнями (Правила Мандели) та Європейські пенітенціарні правила. У статті 65 Мінімальних стандартних правил поводження 3 ув'язненими зазначено, що «в тюремному закладі, в якому знаходиться 
достатня кількість ув'язнених, що належать до одного і того ж віросповіданням, слід призначати кваліфікованого служителя даного культу або дозволяти йому відправляти там відповідні обряди. Якщо кількість таких в'язнів досить значна і $є$ відповідні умови, то для богослужінь варто призначати відповідний час. Кваліфікований служитель культу, який призначається або допускається до тюремної установи на основі пункту 1 цих Правил, повинен мати можливість регулярно проводити релігійні обряди, і у відведений для цього час періодично відвідувати наодинці в'язнів, які належать до його конфесії, для бесід на релігійні теми. В'язнів не можна позбавляти можливості доступу до кваліфікованих представників будь-якого віросповідання. 3 іншого боку, якщо ув'язнений заперечує проти відвідування його служителями культу, до його позиції слід ставитися з повною повагою. У межах практичної можливості кожному ув'язненому повинно бути дозволено задовольняти свої релігійні потреби, беручи участь у релігійних обрядах у стінах тюремної установи, і мати у своєму розпорядженні релігійні писання, властиві його віросповіданню» (статті 65-66). У свою чергу, Європейські пенітенціарні правила вказують, що «кожному ув'язненому дозволяється, по мірі можливості, задовольняти свої потреби релігійного, морального та духовного порядку і для цього бути присутнім на службах або зібраннях у місці позбавлення волі та мати у власному розпорядженні необхідні книги та публікації» (стаття 46).

Свобода релігійної діяльності неповнолітніх регламентується Правилами ООН, які стосуються захисту неповнолітніх, позбавлених волі (прийняті 14.12.1990). Згідно із цими Правилами «кожному неповнолітньому слід дозволяти задовольняти свої потреби, пов'язані $з$ релігійним та духовним життям, в тому числі відвідувати служби і зібрання, що проводяться у його виправному закладі, або брати участь у службах відповідно з обрядами його релігї, а також користуватися необхідними книгами та предметами релігійного культу та навчання відповідно до його віросповідання» [5, с. 48].

Одним із найбільш важливих нормативно-правових актів, які регламентують душпастирську допомогу засудженим, є Основні принципи релігійної свободи і допомоги у в'язниці, прийняті 19.04.2010. Вони грунтуються на вказаних міжнародних нормативно-правових докуменTax.

Таким чином, усі зазначені міжнародні нормативно-правові документи відповідають концепції в'язничного управління, яка традиційно визнає можливість богослужіння для задоволення особистих потреб засуджених. $\mathrm{y}$ місцях ув'язнення посилення ролі релігії та священнослужителів зумовлюється духовними змінами, що відбуваються в сучасному суспільстві. Релігійна діяльність розглядається як один 3 головних аспектів тих свобод і форм надання духовної допомоги, які міцно закріпилися в повсякденному житті в'язниць. Відповідно до цих правил керівництво установ виконання покарань має забезпечити, щоб усі засуджені могли безперешкодно і з гідністю сповідувати свою релігію з розумними обмеженнями, що зумовлюються наявними ресурсами та повсякденною пенітенціарною практикою. 
Міжнародні нормативно-правові документи, які регламентують душпастирську опіку засуджених та осіб, які тримаються під вартою, втілюються у відповідних вітчизняних нормативно-правових документах, а саме:

- Конституція України;

- Закон України «Про свободу совісті та релігійні організації» (прийнятий 23.04.1991);

- Закон України «Про попереднє ув'язнення» (прийнятий 30.06.1993);

- Закон України «Про Державну кримінально-виконавчу службу України» (прийнятий 23.06.2005);

- Закон України «Про внесення змін до деяких законодавчих актів України щодо регулювання діяльності священнослужителів (капеланів) в органах і установах, що належать до сфери управління ДПтС України» (прийнятий 14.05.2015);

- Кримінально-виконавчий кодекс України (прийнятий 11.07.2003);

- Правила внутрішнього розпорядку СІЗО ДКВС України (затверджені 18.03.2013);

- Правила внутрішнього розпорядку УВП (затверджені 29.12.2014);

- Положення про Душпастирську раду при ДПтС України (затверджено 07.09.2015);

- Положення про програму диференційованого виховного впливу «Духовне відродження» (затверджено 16.05.2016);

- Методичні рекомендації про заходи щодо взаємодії з релігійними організаціями 3 питань їх участі в духовному вихованні осіб, які тримаються в установах кримінальновиконавчої системи (затверджені 11.09.1999);

- Статут Української міжконфесійної християнської місії «Духовна та благодійна опіка у місцях позбавлення волі» (затверджений 26.02.2002);

- Угоди між релігійними організаціями та ДКВС України [5, с. 50].

Найважливішими вітчизняними нормативно-правовими документами, які регламентують свободу релігійної діяльності засуджених, $\epsilon$ Конституція та Закони України. У свою чергу, Кримінально-виконавчий кодекс України визначає порядок взаємодії УВП з релігійними організаціями та порядок організації релігійного життя засуджених: у колоніях здійснення свободи сповідувати будь-яку релігію або висловлювати переконання, пов'язані зі ставленням до релігії, підлягають лише тим обмеженням, які необхідні для забезпечення ізоляції, громадської безпеки і встановлені цим Кодексом. Богослужіння і релігійні обряди в колоніях проводять на прохання засуджених або за зверненнями релігійної організації у вільний від роботи час. Засуджені не мають права, посилаючись на свої релігійні переконання, ухилятися від виконання своїх обов'язків, а також установлених вимог режиму відбування покарання. Відправлення релігійних обрядів не повинно порушувати розпорядок дня в установі, а також утискати права інших засуджених. У колонію для відправлення релігійних обрядів можуть бути допущені лише представники релігійних організацій, які офіційно зареєстровані (стаття 128) [6].

Закон України «Про Державну кримінально-виконавчу службу України» визначає, що: «Керівний склад органів та установ ДКВС України сприяє проведенню священнослужителями (капеланами) заходів душпастирської опіки з персоналом» (стаття 23). 
Згідно із Законом України від 14.05.2015 «Про внесення змін до деяких законодавчих актів України щодо регулювання діяльності священнослужителів (капеланів) в органах і установах, що належать до сфери управління ДПтС України» внесено важливі зміни та суттєві доповнення в нормативно-правові документи, які регламентують душпастирську опіку засуджених та осіб, узятих під варту, а саме: унесено зміни до статті 128 Кримінально-виконавчого кодексу України, доповнено цей Кодекс статтею 128-1 «Організація душпастирської опіки засуджених»; унесено зміни до статей 9 і 12 Закону України «Про попереднє ув'язнення» та статті 23 Закону України «Про Державну кримінально-виконавчу службу України».

Не менш важливими для організації душпастирської опіки засуджених та осіб, узятих під варту, $\epsilon$ відповідні накази Міністерства юстиції України: Правила внутрішнього розпорядку СІЗО ДКВС України (наказ від 18.03.2013 № 460/5) та Правила внутрішнього розпорядку УВП (наказ від 29.12.2014 № 2186/5).

Серед угод, укладених між ДКВС України та релігійними організаціями, насамперед варто назвати угоди 3 УПЦ та УГКЦ.

Згідно з Угодою між ДКВС та УПЦ від 26.08.2011 співпраця відбувається за такими напрямами:

1. Сприяння в будівництві храмів та молитовних кімнат в установах кримінально-виконавчої системи, комплектування необхідною літературою, предметами церковного вжитку.

2. Залучення засуджених до позбавлення волі, а також осіб, які перебувають під наглядом кримінально-виконавчих інспекцій, до церко- вного життя, духовно-просвітницька робота із різними категоріями засуджених.

3. Катехізаторська робота та проведення бесід священників з особовим складом ДКВС України.

4. Відзначення та заохочення засуджених до позбавлення волі церковними відзнаками за кращі роботи 3 художньо-прикладної та літературної тематики, за участь у відповідних конкурсах.

5. Участь у науковопрактичних конференціях та зборах як в Україні, так і за її межами.

6. Видавнича діяльність. Видавництво «Молитовника для засуджених», періодичного видання Синодального відділу, а також публікація статей та матеріалів на сторінках періодичних видань ДКВС України.

Варто згадати і про Угоди між ДКВС та УГКЦ від 12.12.2012. Співпраця відбувається за такими напрямами: забезпечення релігійних прав і свобод засуджених та осіб, узятих під варту; пропаганда загальнолюдських цінностей та ідеалів високоморального, відповідального, суспільно корисного і здорового способу життя; благодійна допомога, інформаційна й духовно-просвітницька діяльність, спрямовані на подолання відчуження, соціальної ізоляції осіб, позбавлених волі, на їхнє духовне відродження, а також на профілактику ВІЛ/СНІДу, алкоголізму, наркоманії, залежності від інших психоактивних речовин; сприяння адміністрації УВП і СІ3О у проведенні соціально-виховної роботи із засудженими та особами, узятими під варту, організації їх загальноосвітнього навчання, реалізації освітніх програм із християнської етики; сприяння засудженим, особам, узятим під варту, їхнім сім'ям у відновленні 
та підтриманні соціально корисних зв'язків, допомога адміністраціям установ виконання покарань і слідчих ізоляторів у підготовці засуджених до звільнення; підготовка методичних рекомендацій для проведення духовно-морального виховання, задоволення потреб засуджених і осіб, узятих під варту, у здійсненні Святих Таїнств та інших церковних обрядів; залучення можливостей доброчинних інституцій та окремих благодійників для надання допомоги в будівництві й облаштуванні каплиць та молитовних кімнат на території УВП і CI30 для створення належних умов реалізації духовних потреб засуджених та осіб, узятих під варту; соціальна адаптація та інтеграція засуджених після звільнення; створення та підтримка діяльності центрів соціальної адаптації та інших установ, що здійснюють заходи соціального патронажу звільнених осіб; участь в організації індивідуально-профілактичної роботи із засудженими до покарань у виді громадських та виправних робіт, а також з особами, звільненими від покарання з випробуванням; організація і проведення фестивалів творчості засуджених [5, с. 59].

Висновки. Протягом багатьох десятиліть людство працює над тим, щоб засуджені як члени суспільства зберігали свої права. 3 цією метою прийнято низку міжнародних правових актів, які мають міждержавний характер. Нормативно-правова основа, яка регулює участь релігійних організацій у діяльності УВП, включає міжнародні правові документи, закони України та підзаконні нормативно-правові акти. Вони стабільні, на них не поширюється дія соціальної кон'юнктури, яка віддзеркалює політичні, ідеологічні, економічні, релігійні, історичні та кримінологічні чинники [7].

Релігійний вплив на засуджених уважався визначальним для організації всієї процедури виконання кримінального покарання та досягнення його мети ще з моменту започаткування досліджень проблематики цього покарання, адже мети покарання, що полягає в забезпеченні громадської безпеки і відновлення соціальної гармонії, порушеної злочином, можна досягти лише за умови відновлення гармонії в душі самого злочинця на основі принципів гуманізму та індивідуального підходу.

Однак право на свободу віросповідання в місцях позбавлення волі має свої особливості. Воно повинне здійснюватися так, щоб не порушувати правил внутрішнього розпорядку і не обмежувати права інших осіб. Необхідно, насамперед, на законному рівні розробити та прийняти досконалі правила поведінки із засудженими, які б відповідали Європейським пенітенціарним (в'язничним) правилам та передбачили право ув'язнених вільно сповідувати свою релігію i віру, відвідувати служби або зібрання, користуватися предметами культури і релігійної літератури.

\section{Список використаних джерел}

1. Концепція реформування (розвитку) пенітенціарної системи України: Розпорядження Кабінету Міністрів України від 13.09.2017 р. № 654-р // База даних «Законодавство України / ВР України». URL: https://zakon.rada.gov.ua/laws/show/6542017-р (дата звернення: 24.04.2019). 
2. Стеблинська О. С. Міжнародні стандарти забезпечення прав засуджених як складова діяльності органів та установ виконання покарань. Науковий вісник Інституту кримінально-виконавчої служби. 2014. № 2. С. 49-55.

3. Дахова I. І. Обмеження реалізації права на свободу віросповідання / Форум права. 2017. № 3. C. 27-32. URL: http://nbuv.gov.ua/UJRN/FP_index (дата звернення: 24.04.2019).

4. Жолтані М. І. Релігійний вплив на засуджених при відбуванні кримінального покарання. Науково-практична Інтернет-конференція «Юридична наука і практика: пошук правової гармонії». 2017. Секція № 5. URL: http://legalactivity.com.ua/ index.php?option=com_content\&view=article\&id=1672\%3A091017-17\&catid=195\%3A5102017\&Itemid=241\&lang=ru (дата звернення: 24.04.2019).

5. Пахомов I. В. Особливості духовного виховання засуджених та персоналу Державної кримінально-виконавчої служби України : навчальний посібник. Білоцерківське училище ППП ДКВС України: за заг. ред. проф. Супруна М. О. 2016. С. 122.

6. Кримінально-виконавчий кодекс України: Закон від 11.07.2003 № 1129-IV // База даних «Законодавство України / ВР України». URL: http://zakon2/rada.gov.ua (дата звернення: 24.04.2019).

7. Богатирьов I. Г. Кримінально-виконавче право України: Методичні вказівки до використання модульно-рейтингової технології викладення курсу «Кримінальновиконавче право України». URL: https://westudents.com.ua/glavy/64252-zagalnadeklaratsya-prav-lyudini.html (дата звернення: 24.04.2019).

\section{References}

1. Koncepciya reformuvannya (rozvitku) penitenciarnoyi sistemi Ukrayini: Rozporyadzhennya Kabinetu Ministriv Ukrayini vid 13.09.2017 r. N 654-r // Baza danih «Zakonodavstvo Ukrayini / VR Ukrayini». URL: https://zakon.rada.gov.ua/laws/show/6542017-r (data zvernennya: 24.04.2019) [in Ukrainian].

2. Steblinska, O. S. (2014). Mizhnarodni standarti zabezpechennya prav zasudzhenih yak skladova diyalnosti organiv ta ustanov vikonannya pokaran. Naukovij visnik Institutu kriminalno-vikonavchoyi sluzhbi. 2, 49-55 [in Ukrainian].

3. Dahova, I. I. (2017). Obmezhennya realizaciyi prava na svobodu virospovidannya / Forum prava. 3, 27-32. URL: http://nbuv.gov.ua/UJRN/FP_index (data zvernennya: 24.04.2019) [in Ukrainian].

4. Zholtani, M. I. (2017.). Religijnij vpliv na zasudzhenih pri vidbuvanni kriminalnogo pokarannya, Naukovo-praktichna Internet-konferenciya «Yuridichna nauka i praktika: poshuk pravovoyi garmoniyi». Sekciya 5. URL: http://legalactivity.com.ua/index.php?option =com_content\&view=article\&id=1672\%3A091017-17\&catid=195\%3A5-102017\&Itemid= 241\&lang=ru (data zvernennya: 24.04.2019) [in Ukrainian].

5. Pahomov, I. V. (2016). Osoblivosti duhovnogo vihovannya zasudzhenih ta personalu Derzhavnoyi kriminalno-vikonavchoyi sluzhbi Ukrayini. Bilocerkivske uchilishe PPP DKVS Ukrayini [in Ukrainian].

6. Kriminalno-vikonavchij kodeks Ukrayini: Zakon vid 11.07.2003 N 1129-IV // Baza danih «Zakonodavstvo Ukrayini / VR Ukrayini». URL: http://zakon2/rada.gov.ua (data zvernennya: 24.04.2019) [in Ukrainian].

7. Bogatirov, I. G. Kriminalno-vikonavche pravo Ukrayini: Metodichni vkazivki do vikoristannya modulno-rejtingovoyi tehnologiyi vikladennya kursu «Kriminalno-vikonavche pravo Ukrayini». URL: https://westudents.com.ua/glavy/64252-zagalna-deklaratsya-pravlyudini.html (data zvernennya: 24.04.2019) [in Ukrainian]. 
I. Kuz, Postgraduate of the Criminology and Criminal-Executive Law Chair of the National Academy of Internal Affairs

e-mail: iryna.kuz1771@gmail.com

\section{Legal regulation of the interaction penal institutions with religious organizations}

Nowadays, the process of reforming and improving the penitentiary system continues in Ukraine, which in turn helps to enhance cooperation between the authorities and penal institutions with religious organizations. Only a developed and brought up to international standards penitentiary system can re-socialize a convicted person.

The article deals with the legal principles of engagement of the authorities and penal institutions with religious organizations in the prevention of crime.

Particular attention has been paid to the analysis of international laws and regulations, domestic legislation and subordinate laws and regulations that ensure the right to freedom of religion in places of detention.

Among the analyzed international laws and regulations, the following should be identified: «The Universal Declaration of Human Rights», the Law of Ukraine «On Freedom of Conscience and Religious Organizations», "The Convention for the Protection of Human Rights and Fundamental Freedoms», «The International Covenant on Civil and Political Rights», «European Prison Rules», «UN Rules for the Protection of Juveniles Deprived of their Liberty», «Basic Principles of Religious Freedom and Assistance in Prison», and «Minimum Standard Rules for the Treatment of Prisoners» (Mandela Rules).

Among the domestic legislation, particular attention has been paid to: the Constitution of Ukraine, the Law of Ukraine «On Freedom of Conscience and Religious Organizations», the Law of Ukraine «On Pre-trial Detention», the Law of Ukraine «On the State Criminal Execution Service of Ukraine», the Law of Ukraine «On Amendments to Some Legislative Acts of Ukraine on the Regulation of the Activity of Clergy (Chaplains) in the Authorities and Establishments Belonging to the Management Sphere of the State Penitentiary Service of Ukraine», the Penal Code of Ukraine and other acts.

Thus, generalizing an international experience and domestic legislation in the execution of sentences, it can be stated that the influence of the church is important in formation of the penitentiary policy of the state, the implementation of the penitentiary process and the impact on the resocialization of the convicted persons.

Keywords: citizen rights; human rights; provision human and citizen; penitentiary system; organs and penitentiary establishments; crime prevention; religious organization; chaplain.

Надійшла до редакції 29.04.2019

(C) Кузь I. I., 2019 